\title{
MIDDLE-LATE QUATERNARY GEODYNAMICS OF CRETE, SOUTHERN AEGEAN, AND SEISMOTECTONIC IMPLICATIONS
}

\author{
Caputo R. ${ }^{1}$, Catalano S. ${ }^{2}$, Monaco C. ${ }^{2}$, Romagnoli G. ${ }^{2}$, Tortorici G. ${ }^{2}$, Tortorici L. \\ ${ }^{1}$ University of Ferrara, Department of Earth Sciences, via Saragat 1,44122 Ferrara, Italy, rcaputo@unife.it \\ ${ }^{2}$ University of Catania, Department of Earth Sciences, Corso Italia 55, 95129 Catania, Italy
}

\begin{abstract}
In order to characterize and quantify the superficial deformation occurred during Middle-Late Quaternary in the Southern Aegean, we have systematicaly analyzed the major tectonic structures affecting Crete Island. They typically consist of 10 to $30 \mathrm{~km}$-long dip-slip normal faults, separating carbonate and/or metamorphic massifs, in the footwall block, from loose to poorly consolidated alluvial and colluvial materials within the hanging-wall. All these faults show clear evidence of recent re-activation and trend parallel to two principal directions: WNW-ESE and NNE-SSW. Based on all available data for both onland and offshore structures (morphological and structural mapping, satellite imagery and airphotographs remote sensing as well as the analysis of seismic profiles and the investigation of marine terraces and Holocene raised notches along the island coasts), for each fault we estimate and constrain some of the principal seismotectonic parameters and particularly the fault kinematics, the cumulative amount of slip and the slip-rate. Summing up the contribution to crustal extension provided by the two major fault sets (ca. E-W and ca. N-S) we calculate both radial and tangential (i.e. perpendicular and parallel to the Hellenic Arc, respectively) long-term strain-rates. A comparison of these geologically-based values with those obtained from GPS measurements show a good agreement, therefore suggesting that the present-day crustal deformation is probably active since Middle Quaternary and mainly associated with the seismic activity of upper crustal normal faults characterized by frequent shallow moderate-to strong (Mmax = 7.0) seismic events seldom alternating with stronger (Mmax = 7.5) earthquakes occurring along blind low-angle thrust planes affecting deeper and more external sectors of the Hellenic Arc.
\end{abstract}

Key words: extensional tectonics, thrust tectonics, regional uplift, fault scarp.

\section{Introduction}

The island of Crete in the southernmost sector of the Hellenic Arc is among the most seismically active areas of the whole eastern Mediterranean (Fig. 1). The seismicity is mainly characterized by crustal events, $<25-30 \mathrm{~km}$ in depth (e.g. Pondrelli et al., 2002; Meier et al., 2004), and both shallow instrumental and historical earthquakes show maximum magnitudes up to 7.0 (Fig. 1; Papazachos and Papazachou, 1997; Papanastassiou et al., 2001; National Observatory of Athens Catalogue, 2009; Kiratzi and Louvari, 2003). The available fault plane solutions (Taymaz et al., 1990; Jost et al., 2002; Pondrelli et al., 2002; Kiratzi and Louvari, 2003) indicate a NNE-SSW direction of compression, close to the Hellenic trench further to the south, but within Crete Island and its surroundings an $\mathrm{E}(\mathrm{SE})-\mathrm{W}(\mathrm{NW})$ and a roughly $\mathrm{N}-\mathrm{S}$ extensions prevail associated with ruptures along normal and oblique-slip faults. 


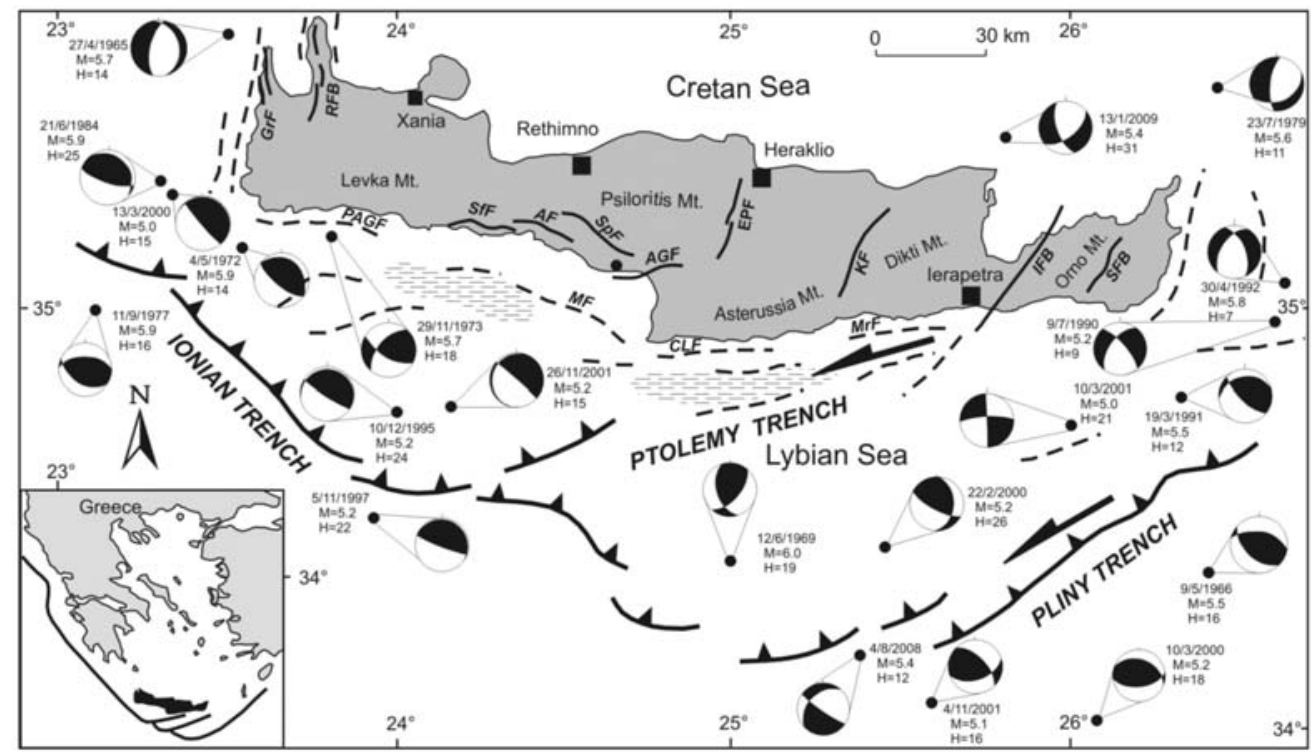

Fig. 1: Simplified tectonic map of the Middle-Late Quaternary active normal faults affecting Crete Island and its surrounding offshore. SfF:Sfakia Fault; AF:Asomatos Fault; SpF:Spili Fault; AGF: Agia Galini Fault; PAGF:Paleochora-Agia Roumeli Fault; MF: Messara Fault; CLF: Cape Lithino Fault; MrF:Mirto Fault; SFB:Sitia Fault Belt; IFB: Ierapetra Fault Belt; KF: Kastelli Fault; EPS: Eastern Psiloritis Fault; RFB: Rodopou Fault Belt; GrF: Gramvousa Fault. Earthquakes and focal mechanisms from Taymaz et al. (1990), Papazachos and Papazachou (1997), Papanastassiou et al. (2001), Jost et al. (2002), Pondrelli et al. (2002), Kiratzi and Louvari (2003) and National Observatory of Athens (2009). Structures located offshore are from Leite and Mascle1 (982), Le Pichon et al. (2002) and Alves et al. (2007).

On the other hand, the rough morphology that characterizes the island also documents the occurrence of an intense Late Quaternary tectonics mainly represented by several hundred meters of regional uplift and at the surface by normal faulting. Indeed, a strong tectonic uplift started about 0.6 Ma ago as recorded by Middle-Late Pleistocene marine terraces (Angelier and Gigout, 1974; Angelier, 1975; 1979; Angelier et al., 1977; Gaki-Papanastassiou et al., 2009) and Holocene raised notches (Pirazzoli et al., 2008; Shaw et al., 2008) as well as by deeply entrenched valleys associated with alluvial and/or transitional coarse-grained sediments along the major depressions.

Crustal scale normal faults affect both offshore (Leite and Mascle, 1982; Le Pichon et al., 2002; Alves et al., 2007) and on land areas (Postma and Drinia, 1993; ten Veen and Mejier, 1998; Fortuin and Peters, 1984; Kokkalas and Doutsos 2001; Monaco and Tortorici, 2004; Caputo et al., 2006), and they consist of 10 to $30 \mathrm{~km}$-long distinct fault segments. These structures generally represent the most impressive morphological features affecting the entire pile of tectonic units of the Alpine orogenic belt (Fassoulas, 1999 and references therein). They run parallel to the principal mountain fronts, commonly bound the major Quaternary basins and show a very young (post-last glacial maximum) morphology documenting their recent activity. On the island of Crete, the Holocene fault-activity is usually easily recognizable when normal fault segments affect hard-rocks because they offset the uniform mountain slopes regularized by the intense Late Pleistocene cryogenetic processes. In several other sectors of the Mediterranean realm, such morphological features have been used to recognise the latest Quaternary tectonic activity along normal faults (Stewart and Hancock, 1991; Armijo et al., 1991; 
1992; Caputo, 1993; Piccardi et al., 1999; Benedetti et al., 2002; Monaco and Tortorici, 2004; Palumbo et al., 2004; Roberts and Michetti, 2004; Papanikolaou et al., 2005; Caputo et al., 2006).

A direct association between earthquakes and crustal tectonic structures occurring both on land and offshore have been suggested only for few normal fault segments (Lyon-Caen et al., 1987; Armijo et al., 1992, Fassoulas, 2001; Monaco and Tortorici, 2004; Caputo et al., 2006).

In order to evaluate the Holocene faulting of Crete and to estimate long-term slip-rates and relations with the major seismotectonic parameters a detailed study of several fault scarps has been carried out combining morphological and structural information based on the analysis of satellite imagery, air photographs, topographic maps and field observations and, for the segments extending offshore, by interpreting available seismic profiles. In addition, information regarding the Pleistocene marine terraces and Holocene raised notches deformation along the southern coast of the island have been carried out in order to estimate the long-term throw-rate along the coast-bounding fault segments. Based on all the collected data we could thus reconstruct the Holocene seismotectonic behaviour of Crete in the frame of the geodynamics that governs the frontal segment of the Hellenic Arc.

\section{Quaternary normal faulting in Crete and surroundings}

Crete Island is characterized by the occurrence of several, mainly dip-slip normal faults bearing evidences of very recent activity. They are typically 10 to $30 \mathrm{~km}$-long and show two major trends: WNW-ESE and NNE-SSW (Fig. 1). These normal faults usually separate Mesozoic carbonate and metamorphic rocks of the Alpine south-verging nappes on the footwall blocks, from coarse-grained alluvial/colluvial Quaternary deposits on the hanging-wall blocks. These structures are characterized by several metres-high and several kilometres-long steeply-dipping scarps that abruptly offset the mountain range (Fig. 2). These features are outstanding in the landscape representing relatively unweathered and vegetation-free zones. Their correlation with recent re-activations of the normal faults is well established worldwide, like in Afar, Greece and Italy and they are interpreted as free faces (Wallace, 1978) due to the cumulative effects of several linear-morphogenic earthquakes (Caputo et al., 2006 and references therein).

During glacial conditions, the weathering and the enhanced sediment mobility along slopes were usually faster than tectonic activity, therefore completely restoring the gradient slope within each interseismic interval. Moreover, glacial climate conditions favoured the formation of the cemented coarse-grained deposits that covered and regularized the mountain slopes continuously burying coseismic surface displacements. Following the last glacial maximum at ca. $18 \mathrm{ka} \mathrm{BP}$, the climate conditions gradually changed and this strongly affected the slope evolution. By reducing the capacity to restore the slope gradient, linear morphogenic earthquakes (i.e. free-faces) could progressively cumulate their effects at the surface (Caputo, 2005). For this reason and according to similar researches carried out along active normal faults within the Mediterranean realm, we conventionally assume a time period of $13 \mathrm{ka}$ for the creation of the fresh tectonic scarps observed in Crete (Benedetti et al., 2002; Papanikolaou et al., 2005; Caputo et al., 2006).

\subsection{WNW-ESE trending faults}

The WNW-ESE fault trend is mainly concentrated along the southern coast of central Crete where they form a $55 \mathrm{~km}$-long fault belt roughly extending from the villages of Sfakia to the west, and Agia Galini to the east. The fault belt consists of some major segments showing well exposed Holocene scarps entirely developed in bedrock. They are the Sfakia (SfF), Asomatos (AF) and Spili (SpF) 

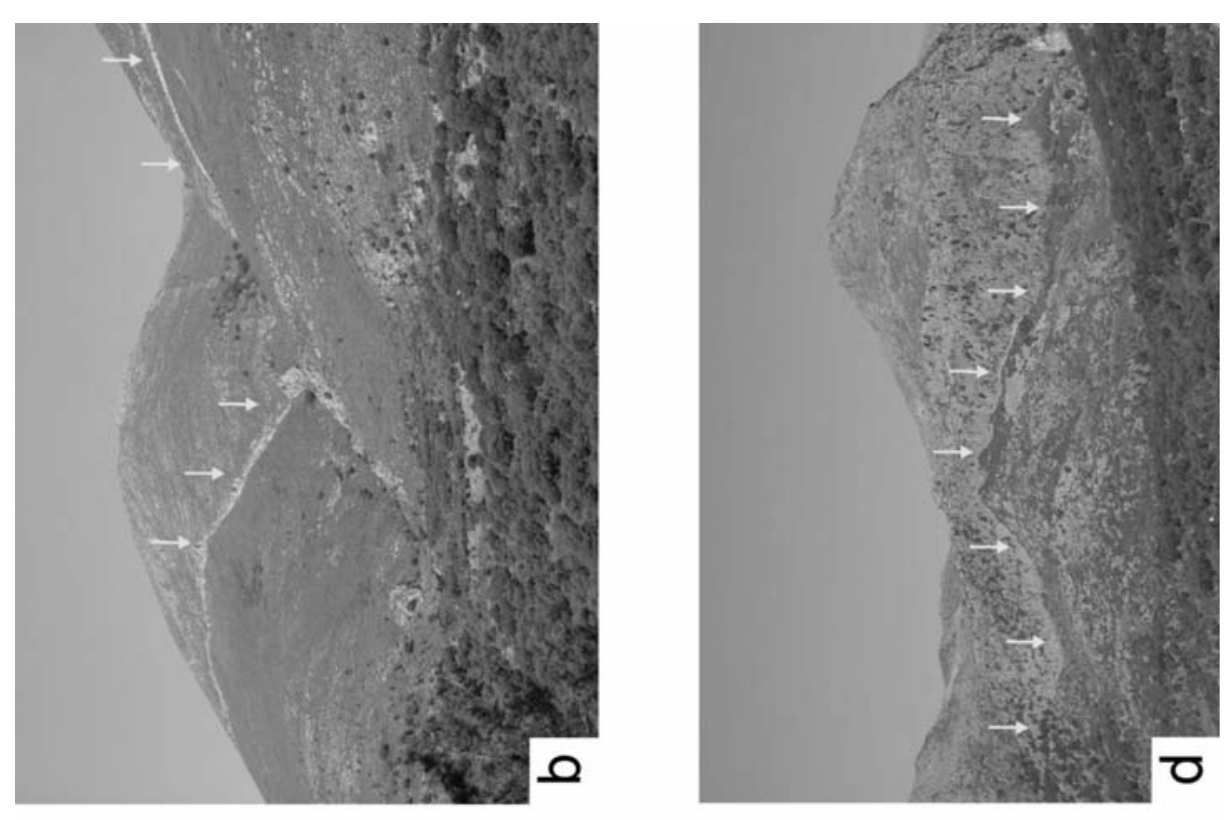

政
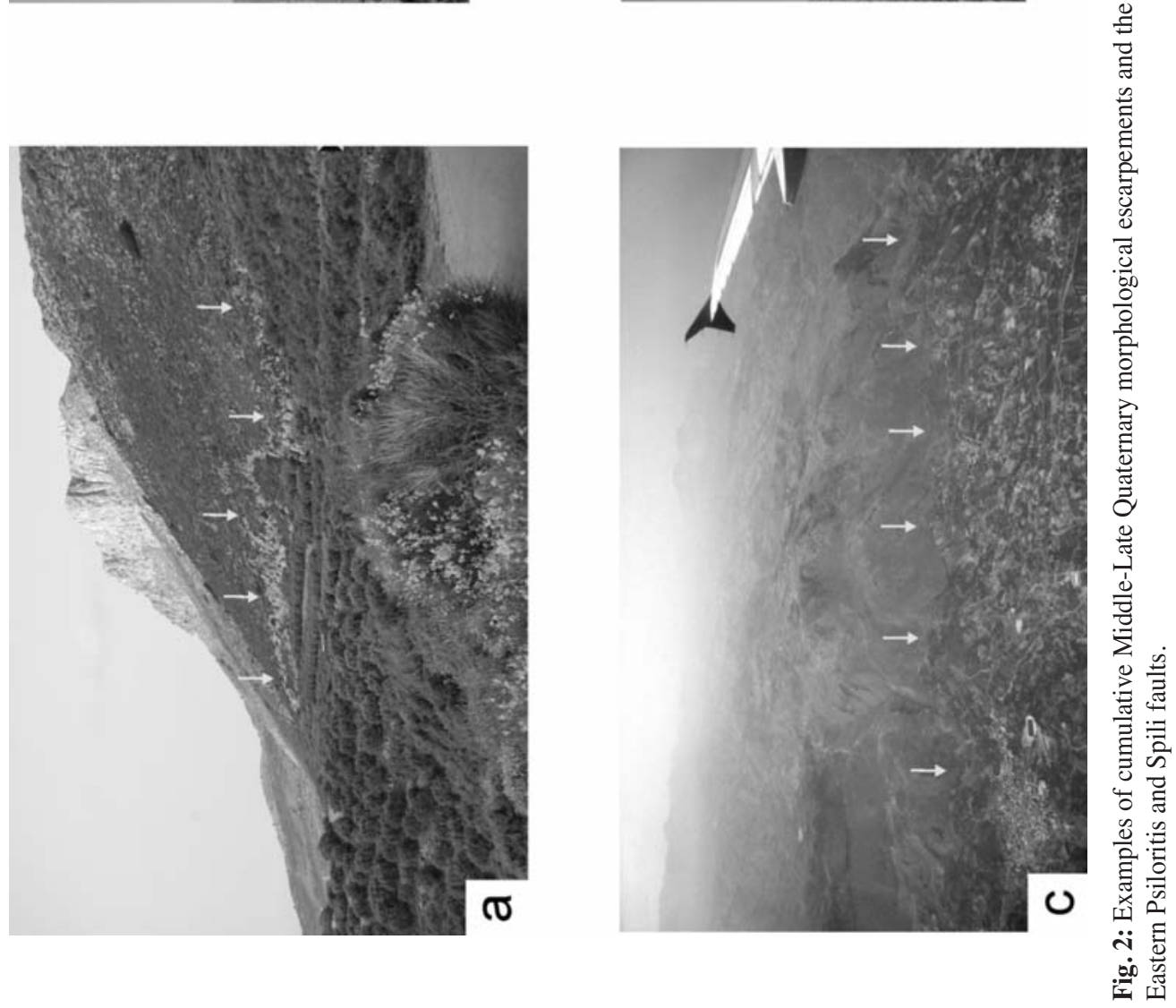
Table 1. Principal seismotectonic parameters of the major active normal faults of Crete and surroundings. L: length of fault segment; D: dip-angle of the fault plane; Tmax: maximum cumulative throw measured along the fault scarp; S: late Quaternary longterm slip-rate; E: long-term extension rate obtained from $\mathrm{S}$ and $\mathrm{D}$.

\begin{tabular}{|c|c|c|c|c|c|c|}
\hline \multicolumn{2}{|c|}{ Fault } & $\begin{array}{c}\mathrm{L} \\
(\mathrm{km})\end{array}$ & $\begin{array}{l}\mathrm{D} \\
\left({ }^{\circ}\right)\end{array}$ & $\begin{array}{c}\operatorname{Tmax} \\
(\mathrm{m})\end{array}$ & $\begin{array}{c}\mathrm{S} \\
(\mathrm{mm} / \mathrm{a})\end{array}$ & $\begin{array}{c}\mathrm{E} \\
(\mathrm{mm} / \mathrm{a})\end{array}$ \\
\hline \multicolumn{7}{|c|}{ WNW-trending fault segments } \\
\hline & Sfakia (SfF) & 16 & $70 \mathrm{~S}$ & 12 & 1.0 & 0.3 \\
\hline & Asomatos (AF) & 9 & $75 \mathrm{~S}$ & 8 & 0.6 & 0.2 \\
\hline & Spili $(\mathrm{SpF})$ & 16 & $65 \mathrm{~S}$ & 10 & 0.8 & 0.4 \\
\hline \multicolumn{7}{|c|}{ NNE-trending fault segments } \\
\hline \multirow{4}{*}{$S F B$} & Zou (ZF) & 5 & $65 \mathrm{~W}$ & 8 & 0.7 & 0.3 \\
\hline & Kalamavki (KaF) & 4 & $65 \mathrm{~W}$ & 8 & 0.7 & 0.3 \\
\hline & Armeni (ArF) & 8 & $70 \mathrm{~W}$ & 6 & 0.5 & 0.2 \\
\hline & Lithini (LiF) & 5 & $70 \mathrm{~W}$ & 4 & 0.3 & 0.1 \\
\hline \multirow{4}{*}{ IFB } & WLastros (LF) & 11 & $60 \mathrm{E}$ & 15 & 1.3 & 0.7 \\
\hline & Sfaka (SF) & 9 & $75 \mathrm{~W}$ & 12 & 1.0 & 0.2 \\
\hline & Ha Gorge (HGF) & 9 & $80 \mathrm{~W}$ & 12 & 0.9 & 0.2 \\
\hline & Kastelli (KF) & 13 & $70 \mathrm{~W}$ & 6 & 0.5 & 0.2 \\
\hline \multirow{3}{*}{$E P F B$} & Agia Varvara (AVF) & 8 & $70 \mathrm{E}$ & 8 & 0.7 & 0.2 \\
\hline & Kroussonas $(\mathrm{KrF})$ & 10 & $70 \mathrm{E}$ & 12 & 1.0 & 0.3 \\
\hline & Tilissos (TF) & 4 & $70 \mathrm{E}$ & 10 & 0.8 & 0.3 \\
\hline \multirow{4}{*}{$R F B$} & Gionas (GF) & 7 & $65 \mathrm{~W}$ & 3 & 0.3 & 0.1 \\
\hline & Rodopos (RF) & 5 & $70 \mathrm{~W}$ & 4 & 0.3 & 0.1 \\
\hline & Kera $(\mathrm{KeF})$ & 7 & $70 \mathrm{~W}$ & 5 & 0.4 & 0.1 \\
\hline & Gramvousa $(\mathrm{GrF})$ & 10 & $70 \mathrm{~W}$ & 8 & 0.7 & 0.2 \\
\hline \multicolumn{7}{|c|}{ Offshore WNW-trending fault segments } \\
\hline & $\begin{array}{l}\text { Paleochora-Agia } \\
\text { Roumeli (PAGF) }\end{array}$ & 25 & 70 & - & 6.4 & 2.2 \\
\hline & Messala (MF) & 30 & 70 & - & $6.1-7.0$ & $2.1-2.4$ \\
\hline & Mirto $(\mathrm{MrF})$ & 25 & 70 & - & 1.4 & 0.5 \\
\hline
\end{tabular}

faults. Another major structure is represented by the Agia Galini fault (AGF) that borders to the north the Plain of Messara.

All these faults display a very sharp morphology, defined by a steep, linear cumulative scarp reaching heights of several hundred meters and locally exhibiting well developed trapezoidal or triangular facets. The fault traces generally bound a major relief, which represents the footwall block and consists of Mesozoic carbonate or metamorphic rocks, running at the base of the mountain front. Morphotectonic evidences like triangular facets, suspended valleys and thick scarp deposits document a Middle-Late Quaternary activity that can be mapped for several kilometers showing segment lengths between 9 and $25 \mathrm{~km}$. These faults are commonly south dipping with angles of $65^{\circ}-80^{\circ}$. 
As above-mentioned, at the base of the major morphological scarp, these faults show the occurrence of 8 to $15 \mathrm{~m}$-high post-glacial scarps, thus documenting the most recent activity. Within the hanging-wall block, alluvial and colluvial wedges are well developed consisting of calcareous breccias and conglomerates thus confirming the continuous footwall uplift. Antecedent streams forming deeply entrenched channels and scarp-related gullies characterize the uplifted block, whereas a lowenergy relief fluvial landscape developed on the hanging-wall block.

Other normal faults exist in the southern offshore part of the island running parallel to the coast line. They are 10 to $25 \mathrm{~km}$-long, WNW-ESE to E-W trending and south-dipping faults. Major evidence of their activity is represented by uplifted Late Quaternary marine terraces and Holocene palaeoshorelines developped in the footwall blocks. Along some of them the seafloor is displaced forming relatively steep scarps reaching heights of about 70-80 m. (Fig. 4 in Alves et al., 2007), thus suggesting that synsedimentary fault activity may have continued up to the present.

\subsection{NNE-SSW trending faults}

The NNE-SSW trending normal fault segments develop all over the island (Fig. 1) forming well defined and discrete belts that, from East to West, are represented by the Sitia and Ierapetra Fault Belts (SFB and IFB, respectively), the Kastelli Fault (KF), the Eastern Psiloritis Fault (EPF), the Rodopou Fault Belt (RFB) and the Gramvousa Fault (GF).

The SFB forms a 18-20 km-long fault belt separating the carbonate sediments and metamorphic rocks of the Alpine nappes from the Upper Miocene-Pliocene sequences and locally the Holocene (?) lacustrine plain of Handras-Armeni (I.G.M.E., 1959; ten Veen and Postma, 1999). Three major fault segments could be recognized. Single segments are typically characterized by cumulative escarpments up to $200 \mathrm{~m}$ and 5-10 m-high fresh (Holocene) scarps at their base. Fault segments are dipping $65^{\circ}-70^{\circ}$ westwards and commonly show dip-slip kinematic indicators. Locally an older oblique-slip (dip-slip and left-lateral) generation of slickenlines is also recorded (Fortuin and Peters, 1984; Kokkalas and Doutsos, 2001).

Also the IFS consists of few major segments for a whole length of $25 \mathrm{~km}$ in a NNE-SSW direction separating the Ierapetra-Kavousi alluvial plain, to the west, from the Orno-Tripti massifs, to the east, consisting of carbonate sediments and metamorphic rocks (I.G.M.E., 1959). Single segments are 8.5 to $11 \mathrm{~km}$-long and commonly dip $75^{\circ}-80^{\circ}$ westwards. They are characterized by $300-800 \mathrm{~m}$-high cumulative Quaternary escarpments and at their base 8-14 m-high fresh scarps provide clear evidence of post-last glacial maximum re-activations (Caputo et al., 2006). Dip-slip striations prevail though older sinistral slickenlines have been locally observed. Other morphological features like V-shaped and suspended valleys characterize the footwall block, while syntectonic carbonate breccias widely occur in the hanging-wall.

Similar geological and morphotectonic features can be observed associated with and along the KF, EPF and GF (Fig. 2) documenting their Middle-Late Pleistocene and Holocene activity (Armijo et al., 1996; Fassoulas, 2001; Mouslopoulou et al., 2001).

\section{Discussion and conclusions}

Based on all available information just briefly described in the previous section, it is thus possible to calculate the slip-rate of the major faults affecting Crete Island. The results show that for the NNE-SSW trending fault segments, slip-rates range between 0.5 and $1.3 \mathrm{~mm} / \mathrm{a}$ whereas for the WNW-ESE trending normal fault segments the slip-rates vary from 0.8 and $1.2 \mathrm{~mm} / \mathrm{a}$. As concerns 
the offshore faults, slip-rates have been estimated based on uplifted palaeocoastlinefootwall uplift/hanging-wall downdrop $(\mathrm{u} / \mathrm{d})$ ratio . Accordingly, in the eastern sector it is possible to calculate slip-rate $1.4 \mathrm{~mm} / \mathrm{a}$. the western offshore we must also consider the uplift contribution the $365 \mathrm{AD}$ thrust-related earthquake (Pirazzoli et al., 1996; Stiros, 2001; Papadimitriou and Karakostas, 2008; Shaw et al., 2008; Ganas and Parsons, 2009). Indeed, in this coastal sector, Early Byzantine palaeocoastlines are found at 9 m-height (Pirazzoli et al., 1996), but the results of numerical models simulating the NE-dipping thrust plane re-activation and associated surface deformation do not fully support such a large uplift. Once separated the regional, thrust-related uplift, it is thus possible to estimate the contribution provided by normal faulting along the western offshore of the island, which is as high as $6 \mathrm{~mm} / \mathrm{a}$.

Eventually, by summing up the contribution to crustal extension provided by all normal faults belonging to the two major sets (ca. E-W and ca. N-S), we calculated both radial and tangential (i.e. perpendicular and parallel to the Hellenic Arc, respectively) long-term strain-rates. A comparison of these geologically-based values with those obtained from GPS measurements (Hollestein et al., 2008) show a good agreement, therefore suggesting that the present-day crustal deformation is probably active since Middle Quaternary and mainly associated with the seismic activity of upper crustal normal faults characterized by frequent shallow moderate-to-strong ( $\mathrm{Mmax}=7.0$ ) seismic events seldom alternating with stronger $(\mathrm{Mmax}=7.5)$ earthquakes occurring along blind low-angle thrust planes affecting deeper and more external sectors of the Hellenic Arc, which now represent the most internal sectors of the Eastern Mediterranean accretionary wedge.

\section{References}

Alves, T.M., Lykousis, V., Sakellariou, D., Alexandri, S. and Nomikou, P., 2007. Constraining the origin and evolution of confined turbidite systems: southern Cretan margin, Eastern Mediterranean Sea $\left(34^{\circ} 30-36^{\circ} \mathrm{N}\right)$. Geo-Marine Lett., 27, 41-61.

Angelier, J., 1975. Sur les plates-formes marines Quaternaires et leurs deforamtions: les rivages meridionaux de la Crete orientale (Grece). C.R. Acad. Sc. Paris, 281, 1149-1152.

Angelier, J., 1979. Néotectonique de l'Arc égéen. Soc. Geol. Du Nord, 3, 418 pp.

Angelier, J., Gigout, M.,1974. Sur les plates-formesmarines et la neotectoniqueQuaternaires de la region d'Ierapetra (Crete, Grece). C. R. Acad. Sc. Paris, 278, 2103-2106.

Angelier, J., Gigout, M. and Hogrel, M.Th., 1977. A propos du gisement tyrrhenien d'Arvi (Crete): Cadre stratigraphique, faune, equisse paleoecologique. Ann. Geol. Pays Helleniques, 28, 471-488.

Armijo, R., Lyon-Caen, H. and Papanastassiou, D., 1991. A possible normal-fault rupture for the 464 BC Sparta earthquake. Nature, 351, 137-139.

Armijo, R., Lyon-Caen, H., Papanastassiou, D., 1992. East-west extension and Holocene normal-faults scarps in the Hellenic arc. Geology, 20, 491-494.

Armijo, R., Meyer, B., King, G.C.P., Rigo, A. and Papanastassiou, D., 1996. Quaternary evolution of the Corinth Rift and its implications for the Late Cenozoic evolution of the Aegean. Geophys. J.Int., 126, $11-53$.

Benedetti, L., Finkel, R., Papanastassiou, D., King, G., Armijo, R., Ryerson, F., Farber, D. and Flerit, F., 2002. Post-glacial slip history of the Sparta fault (Greece) determined by $36 \mathrm{Cl}$ cosmogenic dating: evidence for non-periodic earthquakes. Geophys. Res. Lett., 29, 87-1/87-4.

Caputo, R., 1993. Morphotectonics and kinematics along the Tirnavos Fault, northern Larissa Plain, mainland Greece. Zeit. Fur Geomorph., 94, 167-185.

Caputo, R., 2005. Ground effects of large morphogenic earthquakes. J. Geodyn., 40, 113-118. 
Caputo, R., Monaco, C. and Tortorici, L., 2006. Multiseismic cycle deformation rates from Holocene normal fault scarps on Crete (Greece). Terra Nova, 18, 181-190.

Fassoulas, C., 1999. The structural evolution of central Crete: insight to the tectonic evolution of the South Aegean (Greece). J. Geodyn., 27, 23-43.

Fassoulas, C., 2001. The tectonic development of a Neogene basin at the leading edge of the active European margin: the Heraklion basin, Crete, Greece, J. Geodyn., 31, 49-70.

Fortuin, A.R. and Peters, J.M., 1984. The Prina Complex in eastern Crete and its relationship to possible Miocene strike-slip tectonics. J. Struct. Geol., 6, 459-476.

Gaki-Papanastassiou, K., Karymbalis, E., Papanastassiou, D. and Maroukian, H., 2009. Quaternary marine terraces as indicators of neotectonic activity of the Ierapetra normal fault SE Crete (Greece). $\mathrm{Ge}$ omorphology, 104, 38-46.

Ganas, A. and Parsons, T., 2009. Three-dimensional model of Hellenic Arc deformation and origin of the Cretan uplift. J. Geophys. Res., 114, doi:10.1029/2008JB005599

Hollestein, C., Muller, M. D., Geiger, A. and Kahle, H. G., 2008. Crustal motion and deformation in Greece from a decade of GPS measurements, 1993-2003. Tectonophys, 449, 17-40, doi: 10:1016/j.tecto.2007.12.006

Institute of Geology and Mineral Exploration, 1959. Geological map of Greece at scale 1:50.000, sheet Ziros.

Jost, M. L., Knabenbauer, O., Cheng, J. and Harjes, H. P., 2002. Fault plane solutions of microearthquakes and small events in the Hellenic arc. Tectonophys., 356, 87-114.

Kiratzi, A. and Louvari, E., 2003. Focal mechanisms of shallow earthquakes in the Aegean Sea and the sourrounding lands determined by waveform modeling: a new database. J. Geodyn., 36, 251-274.

Kokkalas, S. and Doutsos, T., 2001. Strain-dependent stress field and plate motions in the south-east Aegean region. J. Geodyn., 32, 311-332.

Le Pichon, X., Lallemant, S. J., Chamot Rooke, N., Lemeur, D. and Pascal, G., 2002. The Mediterranean Ridge backstop and the Hellenic nappes. Marine Geol., 186, 111-125.

Leite, O. and Mascle, J., 1982. Geological structures on the South Cretan continental margin and Hellenic Trench (eastern Mediterranean). Marine Geol., 49, 199-223.

Lyon-Caen, H., Armijo, R., Drakopoulos, J., Baskoutass, J., Delibassis, N., Gaulon, R., Kouskouna, V., Latoussakis, J., Makropoulos, K., Papadimitriou, P., Papanastassiou, D. and Pedotti, G., 1987. The 1986 Kalamata (South Peloponnesus) earthquake: detailed study of a normal fault, evidences for eastwest extension in the Hellenic arc. J. Geophys. Res., 93, 14967-15000.

Meier, T., Rische, M., Endrun, B., Vafidis, A. and Harjes, H.-P., 2004. Seismicity of the Hellenic subduction zone in the area of western and central Crete observed by temporary local seismic networks. Tectonophysics, 383, 149-169.

Monaco, C. and Tortorici, L., 2004. Faulting and effects of earthquakes on Minoan archaeological sites in Crete (Greece). Tectonophysics, 382, 103-116.

Mouslopoulou, V., Andreou, C., Atakan, K. and Fountoulis, I., 2001. Paleoseismological investigations along the Kera fault zone, western Crete: implications for seismic hazard assessment. Bull. Soc. Geol. Greece, 34, 1531-1537.

National Observatory of Athens, 2009. Earthquake catalogue of Greece, Web site www.gein.noa.gr

Palumbo, L., Benedetti, L., Bourlès, D., Cinque, A. and Finkel, R., 2004. Slip history of the Magnola fault (Apennines, Central Italy) from $36 \mathrm{Cl}$ surface exposure dating: evidence for strong earthquakes over the Holocene. Eart Planet. Sci. Lett., 225, 163-176.

Papadimitriou, E. E. and Karakostas, V., 2008. Rupture model of the great AD 365 Crete earthquake in 
the southwestern part of the Hellenic Arc. Acta Geophysica, 56, 293-312.

Papanastassiou, D., Lataoussakis, J. and Stavrakakis, G., 2001. A revised catalogue of earthquakes in the broader area of Greece for the period 1950-2000. Bull. Soc. Geol. Greece, 34, 1563-1566.

Papanikolaou, I.D., Roberts, G.P. and Michetti A.M., 2005. Fault scarps and deformation rates in LazioAbruzzo, Central Italy: Comparison between geological fault slip-rate and GPS data. Tectonophys., 408, 147-176.

Papazachos, B. and Papazachou, C., 1997. The earthquakes of Greece, Editions ZITI, Thessaloniki, 304.

Piccardi, L., Gaudemer, Y. and Tapponnier, P. and Boccaletti, M., 1999. Active oblique extension in the central Apennines (Italy): evidence from the Fucino region. Geophys. J. Int., 139, 499-530.

Pirazzoli, P. A., Laborel, J. And Stiros, S. C., 1996. Earthquake clustering in the Eastern Mediterranean during historical times. J. Geophys. Res., 101, 6083-6097.

Pirazzoli, P. A., Thommeret, J., Thommeret, Y., Laborel, J. and Montaggioni, L. F., 2008. Crustal block movements from Holocene shorelines: Crete and Antikithera (Greece). Tectonophys., 86, 27-43.

Pondrelli, S., Morelli, A., Ekström, G., Mazza, S., Boschi, E. and Dziewonski, A.M., 2002. EuropeanMediterranean regional centroid-moment tensors: 1997-2000. Phys. Earth Planet. Int., 130, 71-101.

Postma, G. and Drinia, H., 1993. Architecture and sedimentary facies evolution of a marine, expanding outer-arc half-graben (Crete, Late Miocene). Basin Res., 5, 103-124.

Roberts, G. and Michetti, A.M., 2004. Spatial and temporal variations in growth rates along active normal fault systems: an example from The Lazio-Abruzzo Apennines, central Italy. J. Struct. Geol., $26,2,339-376$.

Shaw, B., Ambraseys, N. N., England, P. C., Floyd, M. A., Gorman, G. J., Higham, T. F. G., Jackson, J. A., Nocquet, J. M., Pain, C. C. and Piggot, M. D., 2008. Eastern Mediterranean tectonics and tsunami hazard inferred from the AD 365 earthquake. Nature Geoscience, 1, 268-276.

Stewart, I.S. and Hancock, P.L., 1991. Scales of structural heterogeneity within neotectonic normal fault zones in the Aegean region. J. Struct. Geol., 13, 191-204.

Stiros, S.C., 2001. The AD 365 Crete earthquake and possible seismic clustering during the fourth to sixth centuries AD in the Eastern Mediterranean: a review of historical and archaeological data. $J$. Struct. Geol., 23, 545-562

Taymaz, T., Jackson, J. and Westaway, R., 1990. Earthquke mechanics in the Hellenic Trench near Crete. Geophys. J. Int., 102, 695-731.

ten Veen, J., Meijer, P., 1998. Late Miocene to Recent tectonic evolution of Crete (Greece): geological observations and model analysis. Tectonophys., 298, 191-208.

ten Veen, J.H. and Postma, G., 1999. Neogene tectonics and basin fill patterns in the Hellenic outer-arc (Crete, Greece). Basin Res., 11, 223-241.

Wallace, R.E., 1978. Geometry and rates of change of fault-generated range fronts, north-central Nevada. J.Res. U.S. Geol.Survey, 6, 637-650. 